\title{
Short Communication \\ Luminescence of Dimeric Tl(I)-Complexes: Metal-Metal Interaction in the Electronically Excited State
}

\author{
Frank Sabin and Arnd Vogler* \\ Institut für Anorganische Chemie, Universität Regensburg, W-8400 Regensburg, Bundesrepublik \\ Deutschland
}

Summary.Dimeric diethyldithiocarbamatethallium(I) $\left[E t_{2} \mathrm{NCS}_{2} \mathrm{Tl}\right]_{2}$ shows a red emission at $\lambda_{\max }=608 \mathrm{~nm}$ which undergoes a huge Stokes shift with regard to the excitation maximum at $\lambda=246 \mathrm{~nm}$. It is suggested that the emission originates from a sp excited state which is characterized by strong metal-metal bonding.

Keywords. Dialkyldithiocarbamatethallium(I); Luminescence; Metal-metal interaction.

Lumineszenz von dimeren Tl(I)-Komplexen: Metall-Metall-Wechselwirkung im elektronisch angeregten Zustand (Kurze Mitt.)

Zusammenfassung.Dimeres Thallium(I)diethyldithiocarbamat $\left[E t_{2} \mathrm{NCS}_{2} \mathrm{Tl}\right]_{2}$ zeigt eine rote Emission mit $\lambda_{\max }=608 \mathrm{~nm}$ und eine große Stokes'sche Verschiebung im Bezug auf das Anregungsmaximum von $\lambda=246 \mathrm{~nm}$. Die Emission wird einem sp angeregten Zustand zugeordnet, der durch eine starke Metall-Metall Wechselwirkung charakterisiert ist.

The nature and extent of metal-metal interactions in dimeric $\mathrm{Tl}^{\mathrm{I}}$ compounds has been controversially discussed in recent years $[1,2]$. If both $\mathrm{s}^{2}$ metal centers are close enough an overlap of $\mathrm{s}$ and $\mathrm{p}$ orbitals will generate bonding and antibonding $\sigma_{\mathrm{s}}$ and also $\sigma_{\mathrm{p}} \mathrm{MO}$ s. This simple approach does not yield any metal-metal bonding since the s-derived molecular orbitals are completely filled. However, sp orbital mixing may lead to a certain stabilization of $\sigma_{\mathrm{s}}^{\mathrm{b}}$ and $\sigma_{\mathrm{s}}{ }^{*}$ orbitals. As a result a weak metal-metal bonding could result. This situation is further complicated by relativistic effects [3]. Recent calculations have suggested that metal-metal bonding in $\left(\mathrm{Tl}^{\mathrm{I}}\right)_{2}$ dimers is probably rather weak [2].

On the contrary, relatively strong metal-metal bonding (formal bond order of one) should occur in the lowest-energy sp excited state since an electron is promoted from an antibonding $s$ to a bonding $\mathrm{p}$ orbital. Since $\mathrm{Tl}{ }^{\mathrm{I}}$ compounds are frequently luminescent [4] emission spectroscopy is an excellent tool to study the metal-metal interaction in the excited state. For the present study we selected the dimeric $\left(\mathrm{Tl}^{\mathrm{I}}\right)_{2}$ complexes diethyldithiocarbamatethallium(I) $\left(\left[E t_{2} \mathrm{NCS}_{2} \mathrm{Tl}\right]_{2}, E t=\mathrm{CH}_{3} \mathrm{CH}_{2}, 1\right)$ and 


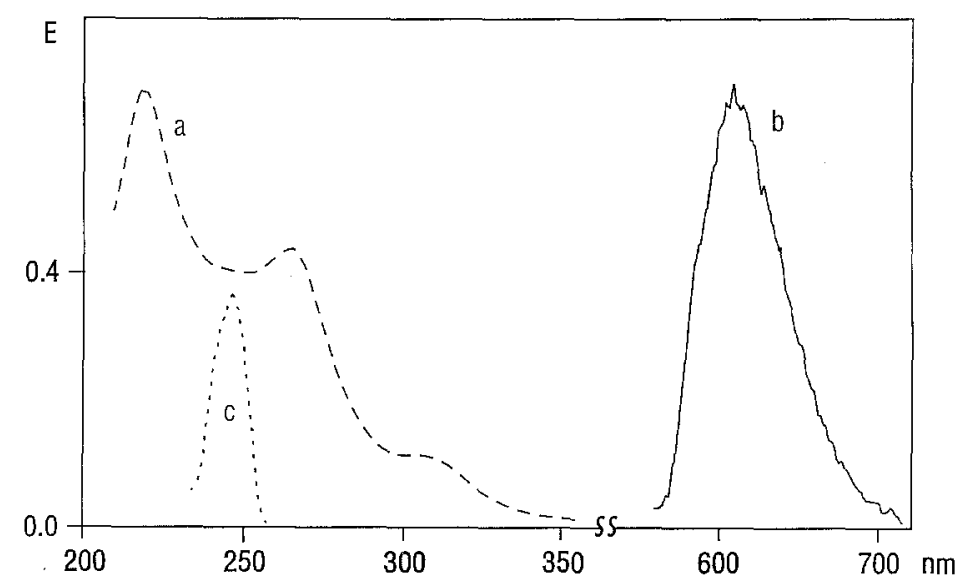

Fig. 1. Electronic absorption (a), emission (b) and excitation spectra (c) of $\left[E t_{2} \mathrm{NCS}_{2} \mathrm{Tl}\right]_{2}(1)$ in relative units. Absorption: $c=1.1 \cdot 10^{-5} M, \mathrm{CH}_{3} \mathrm{CN}, 1 \mathrm{~cm}$ cell. Emission: $c=3.1 \cdot 10^{-6} M, \mathrm{CH}_{3} \mathrm{CN}, 1 \mathrm{~cm}$ cell, $\lambda_{\mathrm{exc}}=240 \mathrm{~nm}$, room temperature. Excitation: $c=3 \cdot 1 \cdot 10^{-6} M, \mathrm{CH}_{3} \mathrm{CN}, 1 \mathrm{~cm}$ cell, $\lambda_{\mathrm{em}}=610 \mathrm{~nm}$, room temperature

di(n-propyl)dithiocarbamatethallium(I) $\left(\left[(n-P r o p){ }_{2} \mathrm{NCS}_{2} \mathrm{Tl}\right]_{2}, n-P r o p=\mathrm{CH}_{3} \mathrm{CH}_{2} \mathrm{CH}_{2}\right.$, 2). In both compounds the $\mathrm{Tl}^{\mathrm{I}}-\mathrm{Tl}^{\mathrm{I}}$ distances are quite different [5]. A comparison of the electronic spectra of both complexes is thus expected to yield important information on the sp excited $\left(\mathrm{Tl}^{\mathrm{I}}\right)_{2}$ dimers.

The absorption spectra of the complexes 1 (Fig. 1) and 2 in $\mathrm{CH}_{3} \mathrm{CN}$ display bands at $\lambda_{\max }=306,266,244$, and $218 \mathrm{~nm}(\varepsilon=10400,35400,32600$, and $59700 \mathrm{~cm}^{-1} M^{-1}$ for $1, \varepsilon=9200,34300,29800$, and $58600 \mathrm{~cm}^{-1} M^{-1}$ for 2). The free ligands $E t_{2} \mathrm{NCS}_{2} \mathrm{Na}$ and (n-Prop) ${ }_{2} \mathrm{NCS}_{2} \mathrm{Na}$ absorb in $\mathrm{CH}_{3} \mathrm{CN}$ at $\lambda_{\max }=300$, 264, 220, and $206 \mathrm{~nm}\left(\varepsilon=11900,10800,9650\right.$, and $\left.14500 \mathrm{~cm}^{-1} M^{-1}\right)$ and $\lambda_{\max }=300,264,226$, and $202 \mathrm{~nm}\left(\varepsilon=12100,11300,6850\right.$, and $\left.12000 \mathrm{~cm}^{-1} M^{-1}\right)$.

The emission of 1 in $\mathrm{CH}_{3} \mathrm{CN}$ at room temperature appears at $\lambda_{\max }=608 \mathrm{~nm}$ (Fig. 1) while 2 was not emissive under these conditions [6]. The excitation spectrum of 1 shows a maximum at $246 \mathrm{~nm}$ (Fig. 1). In methanol both complexes emitted at $\lambda_{\max }=356 \mathrm{~nm}$. Since this emission was nearly identical to that of $\mathrm{T1}^{+}$ions in methanol $\left(\mathrm{TINO}_{3}, \lambda_{\max }=360 \mathrm{~nm}\right)$ it is assumed that the dimeric complexes break off in this solvent. The luminescence of $\mathrm{Tl}^{+}$ions in methanol was quenched by the addition of $\mathrm{CH}_{3} \mathrm{CN}$.

In the complexes 1 and 2 both $\mathrm{Tl}^{\mathrm{I}}$ ions are bridged by two dialkyldithiocarbamate ligands. The four coordinating sulfur atoms form nearly a square which is completed to a distorted octahedron by the $\mathrm{Tl}^{+}$ions. While the $\mathrm{Tl}^{\mathrm{I}}-\mathrm{Tl}^{\mathrm{I}}$ distance of 1 is $3.6 \AA$, it is much longer $(4.0 \AA)$ for 2 [5]. These distances may be compared to those of the metal (3.4 $\AA$ in $\alpha$-thallium [7]) and to the van der Waals radius of the Tl atom $(1.96 \AA)$ [8]. In less polar solvents the dimeric structures are preserved [9]. According to our observations the dimers are also present in $\mathrm{CH}_{3} \mathrm{CN}$ while they are split into monomers in $\mathrm{CH}_{3} \mathrm{OH}$.

The absorption spectra of 1 and $\mathbf{2}$ are rather similar. The bands near 310,270, and $220 \mathrm{~nm}$ are assigned to intraligand transitions since these bands appear also in the spectrum of the free ligand. Both complexes show an additional weak absorption at $240 \mathrm{~nm}$ (Fig. 1) which is assigned to the ${ }^{1} \mathrm{~S}_{0} \rightarrow{ }^{3} \mathrm{P}_{1}$ transition of $\mathrm{Tl}^{\mathrm{I}}$. This 
sp absorption is displayed by $\mathrm{Tl}^{+}$ions in methanol at somewhat shorter wavelength $\left(\mathrm{TlNO}_{3}, \lambda_{\max }=215 \mathrm{~nm}, \varepsilon=8600 \mathrm{~cm}^{-1} M^{-1}[10]\right)$. In the case of 1 this sp absorption coincides also with the excitation band (Fig. 1). Since the energy of the sp transition is almost independent of the $\mathrm{Tl}^{\mathrm{I}}-\mathrm{Tl}^{\mathrm{I}}$ distance it is concluded that the metal-metal interaction in the ground state of the dimeric complexes is rather small.

However, both complexes $\mathbf{1}$ and $\mathbf{2}$ are quite different with regard to their luminescence properties. The emission behavior of 2 is rather similar to that of $\mathrm{Tl}^{+}$ions. The $\mathrm{Tl}^{\mathrm{I}}-\mathrm{Tl} l^{\mathrm{I}}$ distance of $\mathbf{2}$ is apparently so large that the $\mathrm{Tl}^{\mathrm{I}}$ centers do not show any interaction even in the excited state. On the contrary, $\mathbf{1}$ is characterized by an emission at very long wavelength (Fig. 1). This emission is assumed to originate from the $\mathrm{sp}$ excited state of the $\left(\mathrm{Tl}^{\mathrm{I}}\right)_{2}$ dimer. The large Stokes shift of $\Delta \bar{v}=24540 \mathrm{~cm}^{-1}$ is an indication of a strong metal-metal interaction in the electronically excited complex since this shift is only $\Delta \bar{v}=18730 \mathrm{~cm}^{-1}$ for the solvated $\mathrm{Tl}^{+}$ion. The Stokes shift of 1 is caused by a considerable structural change in the excited state. We suggest that the $\mathrm{Tl}^{\mathrm{I}}-\mathrm{Tl}^{\mathrm{I}}$ distance becomes much shorter since in the sp excited state a strong metal-metal interaction leads to stabilization. The short metal-metal distance is associated with a large splitting of $\mathrm{s}$ (and $\mathrm{p}$ ) orbitals in $\sigma_{\mathrm{s}}^{\mathrm{b}}$ and $\sigma_{\mathrm{s}}{ }^{*}$ (and $\sigma_{\mathrm{p}}^{\mathrm{b}}$ and $\sigma_{\mathrm{p}}{ }^{*}$, respectively). While there is no metal-metal bond in the ground state it is then quite strong in the sp excited state. In the dimer 2 the distance between both $\mathrm{Tl}^{\mathrm{I}}$ centers is apparently too large to enable this type of interaction.

It is quite interesting that this type of excited state interaction is not restricted to dimers such as 1 . Two polynuclear $\mathrm{s}^{2}$ complexes, $\left[\mathrm{TlOCH}_{3}\right]_{4}[10]$ and $\left[\mathrm{Sn}_{6} \mathrm{O}_{4}\left(\mathrm{OCH}_{3}\right)_{4}\right][11]$ have been reported to show an emission behavior quite similar to that of 1 . Moreover, the luminescence of cluster compounds of $\mathrm{d}^{10}$ metals [12] such as $\mathrm{Cu}^{\mathrm{I}}[13], \operatorname{Ag}^{\mathrm{I}}[14]$, and $\mathrm{Au}^{\mathrm{I}}[15]$ can be explained by an analogous approach. Both, $\mathrm{s}^{2}$ and $\mathrm{d}^{10}$ metals, are characterized by a filled subshell with spherical electron distribution.

\section{Acknowledgements}

We thank T. Türk for help in collecting data and discussion and W. Dierkes for help in synthesis. Financial support by the Deutsche Forschungsgemeinschaft (DFG) is gratefully acknowledged.

\section{References}

[1] a) Janiak C., Hoffmann R. (1989) Angew. Chem. Int. Ed. Engl. 28: 1688; b) Janiak C., Hoffmann R. (1990) J. Am. Chem. Soc. 112: 5924

[2] Schwerdtfeger P. (1991) Inorg. Chem. 30: 1660

[3] Pyykkö P. (1988) Chem. Rev. 88: 563

[4] Vogler A., Paukner A., Kunkely H. (1990) Coord. Chem. Rev. 97: 285

[5] a) Pritzkow H., Jennische P. (1975) Acta Chem. Scand. A 29: 60; b) Nilson L., Hesse R. (1969) Acta Chem. Scand. 23: 1951

[6] The free ligands $E t_{2} \mathrm{NCS}_{2} \mathrm{Na}$ and (n-Prop) ${ }_{2} \mathrm{NCS}_{2} \mathrm{Na}$ were not emissive under these conditions, too.

[7] a) Wyckoff, R. W. G. (1963) In: Crystal Structures 2nd ed., Interscience Publishers, New York, Vol. 1; b) Wells A. F. (1975) In: Structural Inorganic Chemistry 4th ed., Oxford University Press, London, p. 1013

[8] a) Bondi A. J. (1964) J. Phys. Chem. 68: 441; b) Huheey J. E. (1983) In: Inorganic Chemistry 3rd ed., Harper and Row, New York, p. 259 
[9] Åkerström S. (1965) Ark. kemi 24: 495

[10] Kunkely H., Vogler A. (1991) Inorg. Chim. Acta 186: 155

[11] Kunkely H., Vogler A. (1991) Chem. Phys. Lett. 187: 609

[12] For review see: Kutal C. (1990) Coord. Chem. Rev. 99: 213 and references cited therein

[13] a) Vogler A., Kunkely H. (1986) J. Am. Chem. Soc. 108: 7211; b) Kyle K. R., Ryu C. K., Ford P. C. (1991) J. Am. Chem Soc. 113: 2954; c) Ryu C. K., Kyle K. R., Ford P. C. (1991) Inorg. Chem. 30: 3982

[14] a) Vogler A., Kunkely H. (1989) Chem. Phys. Lett. 158: 74; b) Sabin F., Ryu C. K., Ford P. C., Vogler A. Inorg. Chem. in press

[15] a) Vogler A., Kunkely H. (1988) Chem. Phys. Lett. 150: 135; b) Yam V. W. -W., Lai T. -F., Che C. -M. (1990) J. Chem. Soc. Dalton Trans. 3747

Received February 18, 1992. Accepted February 28, 1992 